\title{
Evaluation of Pre and Post Demerger-Merger Performance: Using ABN AMRO Bank as an Example
}

\author{
Han $\mathrm{Bao}^{1}$ \\ ${ }^{1}$ Edwards School of Business, University of Saskatchewan, Saskatoon, Canada \\ Correspondence: Han Bao, Edwards School of Business, University of Saskatchewan, Saskatoon, Saskatchewan, \\ Canada. Tel: 306-280-3863. E-mail: cocohanbao@gmail.com
}

Received: December 14, 2016

Accepted: January 11, 2017

Online Published: January 20, 2017

doi:10.5539/ijef.v9n2p196

URL: http://dx.doi.org/10.5539/ijef.v9n2p196

\begin{abstract}
This study attempts to measure the impact of simultaneously demerger and merger over the financial performance of ABN AMRO Bank for the period 2007-2013 by using the DuPont system of financial analysis. ABN AMRO Bank N.V. is a Dutch state-owned bank with headquarters in Amsterdam. The bank demerged from Royal Bank of Scotland Group (RBS) in the first quarter of 2010 and merged with Fortis Bank Nederland from July 1, 2010. Two statistical techniques are used in this study; first the analysis of pre and post Demerger-Merger financial ratios is drawn and second paired sample t-test is used. Based on the analysis of 3 years pre and post Demerger-Merger financial ratios and data of ABN AMRO Bank, the result shows that the event of merger-demerger has no significant influence on the bank's Net profit margin, Total asset turnover, Return on equity and Equity multiplier. This research fills the gap of Demerger-Merger analysis in the bank industry by using DuPont system of financial analysis.
\end{abstract}

Keywords: merger, demerger, DuPont analysis, return on equity, net profit margin

\section{Introduction}

Over the last decade, there has been a significant increase in the numbers of cross-border mergers and acquisitions. Among all these companies, financial sector has been experiencing a fierce consolidation and restructuring procedure. At the meantime, Asia and Europe set for demerger boom and research shows that chief executives at the world's biggest companies expect high levels of demerger activity in the future (Anonymous, 2007).

A merger can bring lots benefits to the banks. For instance, in 2010, Australian lender Bendigo and Adelaide Bank says about A $\$ 34$ million (US\$33.81 million) will be added to its net profit through further tax benefits of the merger (Anonymous, 2010). The economies of scale and cost savings can also be achieved from the merger which make banks more competitive in the market. However, evidence from recent US and UK studies reveals a pattern of poor long run post acquisition performance by acquiring firms (Gregory, 2005).

In contrast to the merger, demerger is one of several ways through which a firm may divest a division and improve its focus on its core operation (Singh, 2009). Demergers can also add critical shareholder value by allowing management to rationalize those company divisions or product areas that do not fit with companies' corporate structure. However, demergers are complex and can be extremely time consuming, requiring expert knowledge of accountancy and legal issues to avoid potential pitfalls (Breen, 2005).

Regardless of the complexity of background, in order to make better decision for the future merger or demerger opportunity, it's necessary for bank officers and directors to know the possible impact that can be brought by a merger or demerger deal. While the mergers and demergers have been substantially analyzed in previous literature, less studies can be found analyzing financial performance of company in which both mergers and demergers have taken place simultaneously. This study elaborates on the financial consequence that may come from company's decision of merger and demerger simultaneously by using DuPont analysis. And this study is drawn on the ABN AMRO bank. It is beneficial for the further research in other banks around world.

The paper is organized as follows. Section 1 introducing the merger and demerger. Section 2 discusses the relevant literature review. Research of ABN AMRO Bank and methodology are given in Section 3. In Section 4, DuPont financial ratio analysis and T-test analysis of empirical results of the bank are discussed. The paper ends 
with conclusion in Section 5 .

\section{Literature Review}

As mentioned before, there are numerous theoretical literature examining the impact of merger or demerger on the companies' financial performance. Between them, more work has been done on mergers and acquisitions compared to the demerger part. However, there almost no material can be found that focus on the impact of a merger and demerger happened simultaneously. This is mainly due to the lack of the case in real life since it has high specialty for a company to choose demerger and merger at same time. Therefore, the researches related to merger and the articles about demerger will be discussed separately as follow.

\subsection{Merger Part}

Much studies have been done to analyze the impacts of M\&A on the firms' performance in the banking sector. Calomiris and Karenski (1996) and Caprion (1999) provided evidences that Merger and Acquisition influence the efficiency of most banks positively. While on other hand, another study showed performance is not positively influenced by mergers and acquisitions operations in United States banking industry in terms of efficiency (Amel, Barnes, Panetta, \& Salleo, 2004). Cornett et al. (2006) found that operating performance of merged banks increases appreciably (Cornett, McNutt, \& Tehranian, 2006). Badreldin and Kalhoefer (2009) calculated the companies' return on equity and found the improved performance after merger in the banking sector (Badreldin \& Kalhoefer, 2009). Ong et al. (2011) using pre and post merger accounting and financial data to analyze the financial performance for Malaysian banking sector. They used comparison, ratio analysis, paired sample t-test and DEA approach to measure the bank's efficiency (Ong, Teo, \& Teh, 2011). Kouser and Saba (2011) evaluated the impact of merger on the financial sector of Pakistan through financial ratios and paired t-test. They found that operating financial performance of commercial banks had declined later after the merger (Kouser \& Saba, 2011).

Some researches elaborate the specific relationship between the M\&A deal and changes in financial ratio. Tambi (2005) calculated the performance of the organizations by Profit after Tax, Return on capital employee and Profit before Interest Tax Depreciation and Amortization. He concluded that Merger and Acquisition had been unsuccessful (Tambi, 2005). Pankaj and Sushant (2011) did pre and post analysis of firms and found that mergers can bring a positive effect on the profitability of firms, but liquidity was declined in most of the cases (Pankaj \& Sushant, 2011). Similarly, Sinha and Gupta (2011) studied M\&A in the financial sector of India. The study results proved that profit after tax (PAT) and profit before depreciation, interest, tax and amortization (PBDITA) were enhanced, but the liquidity of firms was reduced (Sinha \& Gupta, 2011).

After reviewing the literature about Merger and Acquisition, it can be concluded that M\&A will influence the performance of organizations. And there is a relationship between M\&A and the financial ratio. It can also be founded that Merger and Acquisition don't have the same impact on the performance of different firms in different part of the world.

\subsection{Demerger Part}

The researches related to the demerger is not as much as those be done on the merger.

Muller (2003) evaluated different modes of disaggregation to create shareholders value and its benefits as well as its shortcomings. He cited an inference that "on an average parent companies and subsidiaries outperform the market, particularly after spin-offs and equity carve-outs. Tracking stocks perform along with the market" (Muller, 2003).

Mallick and Rakshit (2006) made a purposeful comparison between the pre and post demerger financial performance of Dabur India Ltd. They made a conclusion that demerger letting the companies impose widened control, create value for the firm (Mallick \& Rakshit, 2006).

Rakshit and Sujit (2010) measured the financial and operational efficiency of JK Industries by comparing the pre and post demerger period. They found that the companies are getting better financial and operational efficiency after the demerger (Rakshit \& Ghosh, 2010).

From the literature above, it can be found that demerger tend to have positive influence over the company. In most cases, demerger improve the efficiency and the financial situation of the company.

\section{Research and Methodology}

As mentioned in the literature review, financial ratios are the most direct method used extensively in the analysis of financial performance. However, it's mentioned by Sundararajan that "Relaying too heavily on just a few indicators of bank profitability can be misleading" (V. Sundararajan, 2002). 
Therefore, the methodological techniques of Ong et al. (2011) have been followed in this study; two relative techniques have been chosen for this study. First a comparison of DuPont ratio analysis is used for pre and posts Demerger-Merger. Second paired sample t-test is used to check the significant difference in financial performance between pre and post Demerger-Merger.

\subsection{Problem Statement}

The past research reveals the certain financial influence brought by the merger and demerger decision. However, less information is available on the Demerger-Merger impact. The research on banking sector regarding the impacts of merger and demerger has much importance for concerned customers, competitors, future growth, recent management, shareholders etc. Therefore, it's imperative to fulfill the research gap. This research examined the performance effects of ABN AMRO Bank's Demerger-Merger as measured by the financial ratios like net profit margin, total asset turnover, return on equity (ROE) and equity multiplier.

\subsection{Objectives of the Study}

- To analyze the impact of demerger of Royal Bank of Scotland N.V. (RBS) and merger of Fortis Bank Nederland on the financial performance of ABN AMRO Bank

- To evaluate the banks performance in terms of net profitability

- To analyze the performance of the Banks after demerger and merger in terms of return on assets

- To find out the impact of merger on company's equity multiplier

- To examine the effects of merger through asset utilization

- To test the significant difference of financial ratios between Pre and Post Demerger-Merger

\subsection{Scope of the Study}

The current study chose ABN AMRO Bank to evaluate the financial performance of banks from the perspective of pre and post Demerger-Merger. The impact of demerger from Royal Bank of Scotland N.V. (RBS) and merger of Fortis Bank Nederland on the financial performance of ABN AMRO Bank have been evaluated. To compare the performance of Banks, three years pre Demerger-Merger and three years' post Demerger-Merger financial ratios are being computed and compared. The year of merger (2010) was considered as a base year and its financial data are listed as well for the comparison purpose.

\subsection{Sources of Data}

This study is based on secondary data. The financial and accounting data of banks is collected from the Annual report of the selected banks to examine the impact of Demerger-Merger. One thing need to be noticed is that due to the change of bank's name and structure, the financial data of 2007-2009 are from annual report of ABN AMRO Holding N.V., while the financial data 2010-2013 are from annual report of ABN AMRO Group.

\subsection{Financial Parameters}

The performance of the Banks is made in respect of the financial parameters such as Net Profit Margin, Return on Equity, Total Asset Turnover Ratio and Equity Multiplier Ratio in the DuPont model.

The DuPont model was created by F. Donaldson Brown and developed by Saunders. The return on equity model disaggregates performance into three components: net profit margin, total asset turnover, and the equity multiplier (Saunders, 2000).

In order to more effectively evaluate operational managers, Nissim and Penman (2001) suggest using a modified version of the traditional DuPont model in order to eliminate the effects of financial leverage and other factors not under the control of those managers. (Nissim \& Penman, 2001). And the modified DuPont model has become widely recognized in the financial analysis literature,like in the research of Pratt and Hirst (2008), Palepu and Healy (2008), and Soliman (2008). To avoid the limitation of original DuPont model, the modified version of model is used in the following part.

\subsection{Sample: ABN AMRO Bank}

It's a rare case for one bank to go through demerger and merger in the same year. However, in 2010, the ABN AMRO Bank demerged from the Royal Bank of Scotland Group (RBS) and merged with Fortis Bank Nederland three months later. Therefore, ABN AMRO Bank are taken as the sample to evaluate the impact of Demerger-Merger on the performance of the Banks. The brief introduction and important events of the bank are listed as follow.

ABN AMRO Bank N.V. is a Dutch state-owned bank with headquarters in Amsterdam. It is an all-round bank 
servicing retail, private and commercial banking clients (ABN AMRO Group, 2015). It was re-established, in its current form in 2009, following the acquisition and break-up of the original ABN AMRO by a banking consortium consisting of Royal Bank of Scotland Group, Santander Group and Fortis.

After the severe recession in 2009, both the world economy and the Dutch economy started to pick up in 2010, and the recovery was reflected in the results of the bank. However, the dominant theme for ABN AMRO Bank in 2010 was splitting up and merging. Splitting up a bank is a complex endeavour; splitting up a bank and preparing for a merger at the same time is even more complex.

\subsubsection{Demerger-Separation}

Splitting up an integrated bank which is not organized into legal entities implies allocating assets, liabilities and capital among the different parties. ABN AMRO Bank demerged from Royal Bank of Scotland Group (RBS) in the first quarter of 2010. The activities of HBU, IFN Netherlands, two corporate client units and thirteen branches were separated and sold to Deutsche Bank. In addition, Fortis Bank Nederland, which had been dependent on BNP Paribas Fortis for many centralized activities, was successfully separated in (ABN AMRO Group, 2015).

\subsubsection{Merger-Integration}

The Dutch State announced its intention to merge the State-acquired businesses of ABN AMRO and Fortis Bank Nederland in order to create a new, viable bank in 2008. The integration was prepared while the separation activities were still under way.

In April 2010, when the legal separation of the former ABN AMRO Holding was finalized, the retail organization started "two-in-one" bank branches (combined location, separate handling of clients) and closed down 146 branches in the following months.

From 1 July 2010, ABN AMRO Bank N.V. (ABN AMRO) and Fortis Bank (Nederland) N.V. (Fortis Bank Nederland) legally merged and start operating as a single bank under the name of ABN AMRO Bank. And the retail activities were fully integrated in 2010. (ABN AMRO Bank N.V., 2015).

\subsection{Ratios}

Return on equity, ROE, is first decomposed into return on asset, ROA, and the equity multiplier, EM. Return on assets is decomposed into net profit margin and total asset turnover:

$$
\begin{gathered}
R O E=(R O A)(E M) \\
R O A=(N P M)(T A T)
\end{gathered}
$$

Where,

$$
\begin{aligned}
& \text { ROE = return on equity; } \\
& \mathrm{EM} \text { = the equity multiplier; } \\
& \text { TAT = total asset turnover; } \\
& \text { ROA = return on assets; } \\
& \text { NPM = net profit margin. }
\end{aligned}
$$

Return on equity is net income divided by total equity capital and return on assets is net income divided by total assets. The equity multiplier is the ratio of total assets and total equity capital. The net profit margin is net income divided by sales and total asset turnover is net sales divided by total assets.

$$
\begin{gathered}
R O E=(N I) /(T E C) * 100 \\
R O A=(N I) /(T A) * 100 \\
E M=(T A) /(T E C) \\
N P M=(N I) /(N S) * 100 \\
T A T=(N S) /(T A) * 100
\end{gathered}
$$

Where,

$\mathrm{NI}=$ net income;

$\mathrm{TA}=$ total asset;

TEC = total equity capital; 
$\mathrm{NS}=$ net sales.

The DuPont system of financial analysis above provide an efficient way to understand the change of company's financial performance before and after Demerger-Merger.

\section{Results and Discussion}

\subsection{DuPont Analysis of ABN AMRO Bank}

Table 1. Financial profile of ABN AMRO bank

\begin{tabular}{lccccccc}
\hline & \multicolumn{3}{c}{ Pre Demerger-Merger } & Base Year & \multicolumn{3}{c}{ Post Demerger-Merger } \\
\hline & $2007-08$ & $2008-09$ & $2009-10$ & $2010-11$ & $2011-12$ & $2012-13$ & $2013-14$ \\
Net Profit & 9975 & 3595 & $(-4400)$ & $(-414)$ & 689 & 1153 & 1150 \\
Net Sales & 28443 & 20331 & 4768 & 15628 & 9651 & 10159 & 8799 \\
Total Equity Capital & 15998 & 17077 & 18880 & 12099 & 11400 & 12864 & 13555 \\
Total Asset & 1025213 & 666817 & 469345 & 379599 & 404682 & 393758 & 372022 \\
\hline
\end{tabular}

Table 2. Financial performance of ABN AMRO bank

\begin{tabular}{lccccccc}
\hline & \multicolumn{3}{c}{ Pre Demerger-Merger } & \multicolumn{3}{c}{ Base Year } & \multicolumn{3}{c}{ Post Demerger-Merger } \\
\hline & $2007-08$ & $2008-09$ & $2009-10$ & $2010-11$ & $2011-12$ & $2012-13$ & $2013-14$ \\
Net profit Margin & 35.07 & 17.68 & -92.28 & -2.64 & 7.14 & 11.35 & 13.18 \\
Total Asset Turnover & 2.77 & 3.05 & 1.02 & 4.12 & 2.38 & 2.58 & 2.37 \\
Return on Equity & 62.35 & 21.05 & -23.31 & -3.42 & 6.04 & 8.96 & 8.56 \\
Equity Multiplier & 64.08 & 39.05 & 24.85 & 31.37 & 35.50 & 30.61 & 27.45 \\
\hline
\end{tabular}

In Table 1, the core financial data from ABN AMRO Bank's annual consolidated financial statement during 2007-2013 are listed.

Table 2 indicated the core financial ratios of ABN AMRO Bank from 2007 to 2013 used in this analysis. In order to analyze the financial performance of banks after Demerger-Merger. The financial and accounting ratio like net profit margin, total asset turnover, return on equity, and equity multiplier have been calculated.

\subsubsection{Net Profit Analysis}

Net profit margin ratios show how much of each dollar earned by the company is translated into profits and are an indication of how effective a company is at cost control. It's calculated by dividing net profit by net sales. The higher the net profit margin is, the more effective the company is at converting revenue into actual profit.

As mentioned before, in October 2007, a consortium of the Royal Bank of Scotland Group, Fortis and Banco Santander, known as RFS Holdings B.V. acquired the bank, in what was the world's biggest bank takeover to date (ABN AMRO Bank N.V., 2015). This takeover brought huge profit to the bank which is mainly come from the profit from discontinued operations amount to 8177 million euros in its 2007 financial statement. It also made this year's net profit increased to the historical level of 9975 million euros. Thus, the 2007 net profit margin is as high as 35.07 percent, which massively exceeds other year's number.

The 2008 is another special year for ABN AMRO Bank, its owner RBS and Fortis ran into serious trouble: the large debt created to fund the takeover had depleted the banks' reserves just as the financial crisis of 2007-2010 started (ABN AMRO Bank N.V., 2015). As a result, the Dutch government stepped-in and bailed out Fortis in October 2008. Therefore, although the net sales almost remained the same as the last year, its net profit went down to 3595 million euros and the net profit margin decreased to 17.68 percent.

Due to the further influence of financial crisis, the ABN AMRO Bank had net loss of (-4400) million euros in 2009 , which lead to the abnormal data of negative net profit margin (-92.28 percent) at the same year. The prolonged recession unavoidably influenced the financial performance of bank in 2010 as well, lead to the net loss of (-414) million euros and negative net profit margin (-2.64 percent). However, the bank's restructure made the net sales increased from low of 4768 million euros to 15628 million euros.

After the demerger and merger happened in 2010, the bank's net profit slowly increased in the next three years from a low of 689 million euros in 2011 to 1150 million euros in 2013 with the net sales stay around ten thousand million euros. Correspondingly, the net profit margin increased from 7.14 percent in 2011 to 13.18 percent in 2013. 


\subsubsection{Asset Utilization Analysis}

The asset utilization ratio calculates the total revenue earned for every dollar of assets a company owns. It can be calculated by dividing net sales by total asset. This ratio indicates a company's efficiency in using its assets.

Compared to other ratios in the DuPont model, the total asset turnover ratio of the bank is quite stable during the 2007-2013. The highest amount (4.12 percent) appeared in the 2010, the base year of Demerger-Merger, mainly due to the lowest total asset amount (379599 million euros). The lowest amount (1.02 percent) appeared in the 2009 , which is the result of the lowest net sales (4768 million euros) among all this year.

\subsubsection{Return on Equity Analysis}

One of the most important profitability metrics is return on equity (ROE). It can be derived by dividing net profit by total equity capital, which represents the amount earned by each unit of shareholder equity. It also shows a company's capability to generate cash internally. Generally, higher the return on equity is, more profitable a company is compared to other competitors in its industry.

Similar to the net profit margin, the ABN AMRO Bank had the highest ROE amount (62.35 percent) in 2007 due to high net profit from the acquisition deal. And the negative amount in 2009(-23.31 percent) and 2010(-3.42 percent) is the result of net losses caused by the financial crisis. In the post Demerger-Merger years, the ratios remain steady with slightly increase from 6.04 percent in 2011 to 8.56 percent in 2013 .

\subsubsection{Equity Multiplier Analysis}

The equity multiplier is a variation of the debt ratio, which is any method of determining a company's financial leverage. It can be calculated by looking at a company's balance sheet and dividing the total assets by the total stockholder equity. The data of ABN AMRO Bank shows a larger portion of asset financing of bank is being done through debt. Although average of the ratio had declined after the Demerger-Merger, the bank still has a high amount of financial leverage. Financial leverage can be a two-sided sword. Some companies may use financial leverage wisely to finance assets that will pull the company out of debt in the long run. However, as with any individual or company, the greater the debt used to finance assets, the greater the risk (wiseGEEK, 2015). Therefore, the investment risk of ABN AMRO Bank has slightly decreased after Demerger-Merger process.

Since the total asset of the bank decrease from the 1025213 million euros in 2007 to the 372022 million euros in 2013, which almost shrinks to the one-thirds of the original one, and there is no big variation in total equity capital during this years, the equity multiplier declined from the highest amount of 64.08 percent in 2007 to the 27.45 percent in 2013.

\subsection{T-test Analysis of ABN AMRO Bank}

\subsubsection{Hypotheses Statements}

From previous sections, we can infer that merger and demerger have complicated impacts on the performance of organizations. This study is conducted on the ABN AMRO Bank to evaluate the impact of merger and demerger happened simultaneously on the financial performance. Therefore, following are the assumptions towards the hypothesis statements of the study:

\section{Testing the significant difference between Pre and Post Demerger-Merger Net Profit Margin}

H0 (Null Hypothesis): There is no significant difference between pre and post Demerger-Merger Net Profit Margin.

H1 (Alternative Hypothesis): There is a significant difference between pre and post Demerger-Merger Net Profit Margin.

\section{Testing the significant difference between Pre and Post Demerger-Merger Total Asset Turnover}

H0 (Null Hypothesis): There is no significant difference between the pre and post Demerger-Merger Total Asset Turnover.

H1 (Alternative Hypothesis): There is a significant difference between the pre and post Demerger-Merger Total Asset Turnover.

\section{Testing the significant difference between Pre and Post Demerger-Merger Return on Equity}

H0 (Null Hypothesis): There is no significant difference between the pre and post Demerger-Merger Return on Equity.

H1 (Alternative Hypothesis): There is a significant difference between the pre and post Demerger-Merger Return 
on Equity

\section{Testing the significant difference between Pre and Post Demerger-Merger Equity Multiplier}

H0 (Null Hypothesis): There is no significance difference between the pre and post Demerger-Merger Equity Multiplier.

H1 (Alternative Hypothesis): There is a significant difference between the pre and post Demerger-Merger Equity Multiplier.

\subsubsection{T-test Data Analysis}

Table 3. Mean and standard deviation of pre demerger-merger and post demerger-merger ratios of ABN AMRO bank

\begin{tabular}{llllll}
\hline & & Mean & Std.Deviation & P-value & Sig. \\
\hline Net profit Margin & Pre & -13.18 & 69.06 & 0.62 & 0.62 \\
& Post & 10.56 & 3.10 & & 0.81 \\
Total Asset Turnover & Pre & 2.28 & 1.10 & & 0.81 \\
& Post & 2.44 & 0.12 & 0.68 & 0.68 \\
Return on Equity & Pre & 20.03 & 42.84 & & \\
\multirow{2}{*}{ Equity Multiplier } & Post & 7.85 & 1.58 & 0.34 & 0.33 \\
& Pre & 42.66 & 19.86 & & \\
\hline
\end{tabular}

In Table 3, the mean, standard deviation, $\mathrm{t}$ value and significance of financial ratios during pre and post Demerger-Merger period are listed separately. All the financial and accounting ratios above have been computed by the researcher's.

The merger of the ABN AMRO Bank N.V. with the Fortis Bank Nederland is shown and then the financial performance between the Pre\& Post Demerger-Merger has been compared on the basis of key ratios. It is found that there is a significant increase in the mean of net profit margin (-13.18 percent Vs 10.56 percent) and P-value equals 0.62 . The mean of net profit margin increased after the Demerger-Merger so the bank's performance has improved in the post Demerger-Merger period. The data also shows that there is almost no difference in the mean of total asset turnover (2.28 percent Vs 2.44 percent) and P-value equals 0.81 . It is found that the mean value of gross profit margin has increase, but it doesn't show significant. The mean value of return on equity of bank has been decreased from 20.03 percent to 7.85 percent after merger, which indicated that bank gave more returns to the equity shareholders after Demerger-Merger. And P-value equals 0.68, which means there is no significance. Last but not the least, the equity multiplier shows no significance with mean value (42.66 percent Vs 31.19 percent) and P-value 0.34. However, the decrease of equity multiplier indicates that the leverage structure of bank was improved which directly increased the performance of the banks. The majority of financial parameters analyzed above indicate that bank's performance has been slightly improved after Demerger-Merger.

The result of the ' $t$ ' test shows that the difference in the Net Profit Margin, Total Asset Turnover, Return on Equity and Equity Multiplier is not significant statistically, therefore, the $\mathrm{H} 0$ is accepted, which means that there is no significant difference between the pre and post Demerger-Merger financial performance in case of the ABN AMRO Bank. However, there are differences in absolute terms.

All the standard deviations of the financial ratios went down after the Demerger-Merger. The biggest drop of standard deviation occurred at the net profit margin, from 69.06 to 3.10. At the meantime, the return on equity and equity multiplier declined from 42.84 to $1.58,19.86$ to 4.06 , separately. While the standard deviations of total asset turnover changed from 1.10 to 0.12 , which is a small decline compared to the other three ratios. The decline of standard deviation means the bank had less volatility after the Demerger-Merger, which bring less financial risk to its operation. In this aspect, the overall financial performance of the bank has been improved.

\section{Summary and Conclusion}

The banking industry is one of the rapidly growing industries around the world. Through Mergers and acquisitions, some banks achieved significant growth. And by going through the demerger, the banks can unlock shareholder value, improve company focus, help to eliminate negative synergies and free up capital. However, the poor long run post merger performance of many companies and some entrepreneurs' ambitions to rush into a merger deal has bring concern to the question that what's the financial impact of a merger or demerger. 
Numerous studies have been done to determine the impact of merger or demerger on the bank and other financial sectors. This research fills the gap of Demerger-Merger analysis in the bank by using DuPont analysis. The study purpose is to assess the impact of Demerger-Merger on the financial performance of ABN AMRO Bank. Two statistical techniques are used in this study; first the analysis of pre and post Demerger-Merger financial ratios is drawn and second paired sample t-test is used.

Based on the analysis of 3 years pre and post Demerger-Merger financial ratios and data of ABN AMRO Bank, the result shows that there is insignificant difference in the financial performance of banks between pre and post Demerger-Merger. That means the performance of banks is not improved neither regressed through the implementation of Demerger-Merger. However, the financial data of bank shows the slightly increase in profitability, efficiency, liquidity, and leverage ratio(s). The recession brought by the 2008 financial crises can contribute to the reasons why bank didn't improve a lot after the demerger and merger.

This research provides an insight picture for financial and non-financial institutions to consider the use of Demerger-Merger as a special approach, and the investors and stockholders should be familiar about financial performance of Demerger-Merger in the industry. It is recommended to bank officers and directors that they should prudently consider the potential impact involved in a Demerger-Merger decision before choosing and accepting for Demerger-Merger. The banks, which are not performing well can consider the Demerger-Merger option after the review of the past cases and detailed research of its situation.

\subsection{Limitations of the Study}

- This study is a secondary based research. Therefore, financial data taken for the study are limited to the belief that they expose the reality and an accurate picture.

- This study is based upon only one single case as sample study, which restricts the generalization of the results.

- There is limited research on the bank deal with demerger and merger at the same time, so no historical comparison is made in this article.

- The bank is running in a complicated environment, some possible influential factors are not identified in this article.

- Since the analysis here include the data of financial crisis period from 2008 to 2010, the accuracy of the result should consider the possible influence of this factor.

\subsection{Scope for Future Research}

- Future research should consider taking more cases.

- Since bank is only a specific type of business, future study can be done to compare the result of Demerger-Merger impact in different industries.

- Future research can be done to consider the practical influence of Demerger-Merger, for instance, the employment and management problem caused by the restructuring of the bank.

- Future studies should evaluate more variables including external profitability determinants, such as inflation, GDP growth rate, exchange rate etc.

\section{Acknowledgments}

The author would like to thank Professor Bo Xie who provided guidance and assistance to the research. I am also grateful to my beloved family for their support.

\section{References}

ABN AMRO Bank N.V. (2015, April 2). Completion of ABN AMRO Bank and Fortis Bank Nederland legal merger. $\quad$ Retrieved

from http://www.abnamro.com/en/newsroom/archive/pressrelease-archive/2010/Completion_of_legal_merger.ht $\mathrm{ml}$

ABN AMRO Group. (2015, April 3). ABN AMRO Group Annual Reports 2010. Retrieved from http://www.abnamro.com/en/about-abn-amro/reports-and-reviews/index.html

Amel, D., Barnes, C., Panetta, F., \& Salleo, C. (2004). Consolidation \& efficiency in the financial sector: A review of the international evidence. Journal of Banking \& Finance, 3, 2493-2519. https://doi.org/10.1016/j.jbankfin.2003.10.013

Anonymous. (2007). Asia and Europe set for demerger boom. International Financial Law Review, 1. 
Anonymous. (2010). Aust'S Bendigo And Adelaide Bank To Get More Merger Tax Benefits. Asia Pulse. Retrieved from http://search.proquest.com/docview/852554057?accountid=14739

Badreldin, A., \& Kalhoefer, C. (2009). The effect of mergers and acquisitions on bank performance in Egypt. Journal of Management Technology, 25, 1-15.

Breen, M. (2005). Analysis: Demergers - How to manage a demerger. Accountancy, 70-71.

Calomiris, C., \& Karenski, J. (1996). The bank merger wave of the 1990s: Nine case studies. University of IIIinois.

Cornett, M. M., McNutt, J. J., \& Tehranian, H. (2006). Performance changes around bank mergers: Revenue enhancements versus cost reductions. Journal of Money, Credit and Banking, 38(4), 1013-1050. https://doi.org/10.1353/mcb.2006.0053

Gregory, A. (2005). The Long Run Abnormal Performance of UK Acquirers and the Free Cash Flow Hypothesis. Journal of Business Finance \& Accounting, 777-814. https://doi.org/10.1111/j.0306-686X.2005.00614.x

Kouser, R., \& Saba, I. (2011). Effects Of business combination on financial performance: Evidence from Pakistan's banking sector. Australian Journal of Business and Management Research, 1(8), 54-64.

Mallick, A. K., \& Rakshit, D. (2006). Corporate Restructuring through Demerger: A Case Study. Finance India, XX(4), 1321-1338.

Muller, M. (2003). Disaggregation: Which way to choose? ICFAI Reader Demerger, 37-42.

Nissim, D., \& Penman, S. (2001). Ratio analysis and valuation: From research to practice. Review of Accounting Studies, 6, 109-154. https://doi.org/10.1023/A:1011338221623

Ong, T. S., Teo, C. L., \& Teh, B. H. (2011). Analysis of financial performance and efficiency changes of Malaysian commercial banks after mergers and acquisitions. International Journal of Business and Management Tomorrow, 1(2).

Rakshit, D., \& Ghosh, S. (2010). Demerger: Sailing with the Global Wind. NSHM Journal of Management Research and Application, 2(1), 22-31.

Saunders, A. (2000). Management of financial institutions (3rd ed.). McGraw Hill.

Singh, R., Bhowal, A., \& Bawari, V. (2009). Impact of Demerger on Shareholders' Wealth. Enterprise Risk Management, 1(1), E4.

Sinha, P., \& Gupta, S. (2011). Mergers and Acquisitions: A Pre-Post Analysis for the Indian Financial Services Sector. Retrieved From mpra.Ub.Uni Muenchen, De/31253/1/Mpra_Paper_31253.

Tambi, M. K. (2005). Impact of mergers \& amalgamation on the performance of Indian companies. Econ WPA Finance, 0506007.

V. Sundararajan, C. E. (2002). Financial soundness indicators: Analytical aspects and country practices. IMF Occasional Paper, 212.

WiseGEEK. (2015, April 2). What is an Equity Multiplier? Retrieved from http://www.wisegeek.com/what-is-an-equity-multiplier.htm

\section{Copyrights}

Copyright for this article is retained by the author(s), with first publication rights granted to the journal.

This is an open-access article distributed under the terms and conditions of the Creative Commons Attribution license (http://creativecommons.org/licenses/by/4.0/). 